(III)）ホスト格子中の Gd(III) の ESR に执いて, これと反対の 傾向の実験事実を報告している。この場合の Gd(III) の site symmetry は $C_{3 h}$ である。ホスト格子の構造から期待ど扣りの 静電モデルで説明できる実験結果を得たが，後者の相反する傾向
はホスト格子の site の違いはあるが，今後の興味ある問題であ る。

終りに本研究の一部は文部省科学研究費補助金により行なった のでここで厚く謝意を表する。

\title{
Electron Spin Resonance of Gd(III) in Single Crystals of Some \\ Lanthanoid(III) Double-nitrates, $\operatorname{Ln}_{2} \mathrm{Mg}_{3}\left(\mathrm{NO}_{3}\right)_{12} \cdot 24 \mathrm{H}_{2} \mathrm{O}$ \\ Seizo Misumi, Toshiyuki Isobe and Toshikatu Higa \\ Inorganic Chemistry Laboratory, Faculty of Science, Kyushu University; Hakozaki, Higashi-ku, Fukuoka-shi 812 Japan
}

\begin{abstract}
Electron spin resonance of $\mathrm{Gd}(\mathrm{III})$ in single crystals of $\mathrm{Ln}_{2} \mathrm{Mg}_{3}\left(\mathrm{NO}_{3}\right)_{12} \cdot 24 \mathrm{H}_{2} \mathrm{O}$ (where $\mathrm{Ln}(\mathrm{III}$ ) denotes $\mathrm{Ce}(\mathrm{III}), \operatorname{Pr}(\mathrm{III}), \mathrm{Nd}(\mathrm{II}), \mathrm{Sm}(\mathrm{III})$, and $\mathrm{Eu}(\mathrm{III})$ ) was studied in $X$ band at room temperature. A seven-line spectrum for $H / / Z$ as well as $H / / X$ and $H / / Y$ corresponding to $\Delta M= \pm 1$ transitions, was observed for all these crystals. The angular variations of the observed spectra were studied and they showed the similar dependence for each host lattice. The experimental data fitted to the effective spin-Hamiltonian for $C_{3 h}$ symmetry. It was found that the empirical, linear relationships exist between the magnitude of the $\mathrm{Gd}($ III) zero-field splitting parameter $b_{2}^{0}$ and (i) the ionic radius of the host lanthanoid(III); (ii) the calculated value of $\left\langle r^{2}\right\rangle$ of the host lanthanoid(III) wave function, which is concerned to lanthanoid contraction.
\end{abstract}

（日本化学会誌, 1973, p. 2043 2047)

\section{$\gamma$ 線照射した酸化デンプンの ESR スペクトル}

（1973 年 5 月 4 日 受 理）

\author{
野沢 靖夫・鈴木 正三・東出 福 司*
}

r線照射したデンプン，ギ酸デンプン，グルコース，アルギン酸ナトリウム，D-グルクロン酸，酸化 デンプン，酸化セルロースについて，室温に拈ける ESR スペクトルを測定した。デンプンにおいては 典型的な二重線が，アルギン酸ナトリウムでは一重線が観測された。酸化デンプンおよび酸化セルロー スではたがいに類似しているが複雑なスペクトルを示した。酸化デンプンのスペクトルは $100^{\circ} \mathrm{C}, 60$ 分 間熱処理することにより $g$ 值がわずかに異なる 2 種類の一重線シグナルの重なった幅広いシグナルに変 化した。熱処理により減衰した ESR シグナルの成分は照射デンプンに見られる二重線シグナルに類似 していた。酸化デンプンー尿素拈よび酸化デンプンーポリビニルアルコールの反応生成物に拈ける結果を あわせ，照射した酸化デンプンに生ずるラジカルの化学的構造について検討した。

\section{1 楮 言}

糖類1) 6) 怙よび多糖類(7) 11) に関する照射ラジカルの研究はいま までにいくつかの報告がある。しかしながら酸化デンプンについ ての報告はいまだ見あたらない。

* 静岡薬科大学, 420 静岡市小鹿

1) D. Williams, J. E. Geusic, M. L. Wolfrom, L. J. McCabe, Proc. Natl. Acad. Sci., (U.S.), 44, 1128(1958).

2) D. Williams, B. Schmidt, M. L. Wolfrom, A. Michelakis, L. J. McCabe, ibid., 45, 1744(1959).

3) A. J. Bailey, A. Barker, J. S. Brimaco, D. Pooley, P. H. Spence, Nature, 190, 259(1961).
著者らは薬物粉体のコーティング材料に薬物透過の特異性を与 える目的で，とくに酸化デンプンに着目し，ポリビニルアルコー ル (PVA) と橋かけ反応を行なわせて，比較的丈夫なしかも $\mathrm{pH}$

4) M. A. Collins, Nature, 193, 1061(1962).

5) H. Ueda, J. Phys. Chem., 67, 966, 2185(1963).

6) J. N. Herak, K. Adamic, R. Blinc, J. Chem. Phys., 42, 2388(1965).

7) R. J. Abraham, D. H. Whiffen, Trans. Faraday Soc., 54, 1291(1958).

8) Z. Kuri, H. Ueda, J. Polym. Sci., 50, 349(1961).

9）上田 寿, 九里善一郎, 志田正二, 日化, 82, 8(1961).

10）三品冏良，濃化， 36，620(1962).

11) K. Adamic, Stärke, 20, 3(1968). 
により透過性が変わるフィルムを試作した。酸化デンプンはアル カリ性に括いて不安定であることから，酸化デンプンに放射線グ ラフト重合した膜も薬物透過の選択性が期待される。これより酸 化デンプンに放射線グラフト重合させる前段階として，本報では まず ESR により被照射酸化デンプンに生ずるラジカル種の化学 的構造について酸化デンプンとの反応生成物に批ける結果をあわ せ，検討を行なった。

\section{2 実験}

\section{1 試 料}

使用したデンプンは日本食品化学工業株式会社製トウモロコシ デンプンを $80 \%$ 含水メタノールで脱脂乾燥した。ブドウ糖，Dグルクロン酸, アルギン酸ナトリウムは市販品を，セルロースは 沪紙をエタノールで脱脂したすの，キ酸デンプンは Gottolieb ${ }^{12)}$ による方法にしたがい，キ酸と反応させたるのを用いた。酸化デ ンプンは Jackson ら ${ }^{18)}$ が行なったと同様の方法により，脱脂デ ンプンを過ヨウ素酸を用いて室温で一昼夜反応させたのち，水水 でよく洗浄したるのを使用した。生成物のアルデヒド基の量は Rankinin) の方法にしたがい，アルデヒド基をナトリウムボロヒ ドリドにより還元させ，発生した水素の量から測定した。その結 果酸化デンプンの場合, ピランース環の $75.2 \%$ がジアルデヒド に酸化されたすのと考光られる。セルロースの酸化はデンプンの 場合とまったく同様の方法により反応時間 70 時間で行なった。 その結果酸化セルロースのアルデヒドの量恃 $34.7 \%$ であった。 酸化デンプンと尿素扰よび PVA との反応は Sloan ${ }^{16)}$ の方法に したがい $80^{\circ} \mathrm{C} て ゙$ 行なった。

\subsection{ESR 測定}

日本電子社製 JES-3 BX 型 ESR 装置を用い，試料を測定用 $5 \mathrm{~mm} \phi$ のガラス管内に $10^{-8} \mathrm{mmHg}$ に脱気封入し, $\mathrm{Mn}^{2+}$ をマ ーカーにして室温で測定した。

\section{$2.3 r$ 線照射}

照射は ${ }^{\circ 0} \mathrm{Co} r$ 線を用い，室温で 20 時間照射した。全線量は 2 Mrad である。

\section{3 結果および考察}

酸化デンプン括よび酸化セルロースの照射直後と熱処理後の ESR スペクトルを四 1，2飞示す。これらのスペクトルは $\Delta H_{\mathrm{m} 81}$ 20〜24 G を有し，わずかに徽細構造が重なって観測される。こ れらのスペクトルは初めて実測されたるのであるがセルロース， デンブン両者とるによく類似しているのが特徵的である。酸化デ ンプンのシグナルは熱処理温度の上昇とともに, 非対称な一重線 に変化した。この結果は後で述べるよらに 2 種以上のシグナルの 混在を仮定すると説明できる。

つぎにデンプソ，キ酸デンプンおよびグルコースの ESR スペ クトルを四3 K示す。いずれる超微細（hf）分裂 13〜16 G の二 重線を示し，わずがシグナルの両翼とその中心に hf が重なっ

12) D. Gottolieb, C. G. Caldwell, R. M. Hixon, J. Amer. Chem. Soc., 62, 3342(1940).

13) E. L. Jackson, C. S. Hadson, ibid., 59, 2049(1937).

14) J.C. Rankin, C. L. Mehltretter, Anal. Chem., 28, 1012 (1956).

15) J. W. Sloan, B. T. Hofrecter, R. C. Millies, I. A. Wolf, Ind. Eng. Chem., 48, 1165(1956).

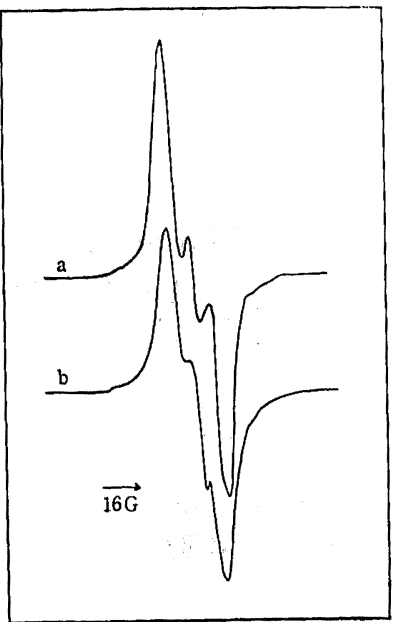

Fig. 1 ESR spectra of irradiated oxystarch (a) and oxycellulose (b)

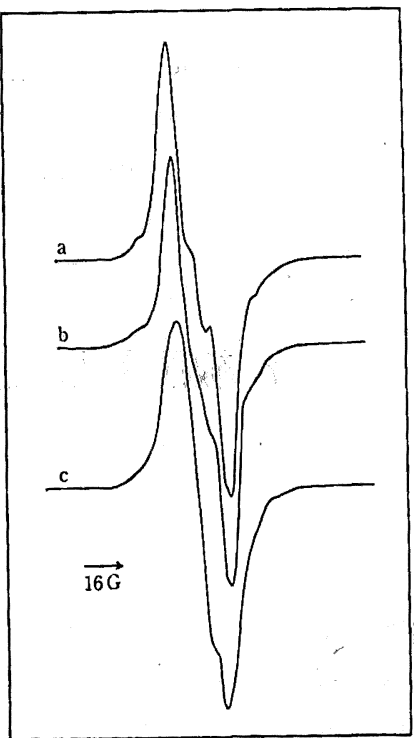

Fig. 2 ESR spectra of irradiated oxystarch After the heat treatment a : At $50^{\circ} \mathrm{C}$ for $30 \mathrm{~min}$
b : At $80^{\circ} \mathrm{C}$ for $30 \mathrm{~min}$
c : At $100^{\circ} \mathrm{C}$ for $100 \mathrm{~min}$

て観測され、シグナルの線幅は $25 \mathrm{G}$ である。 デンプンのスペクトルは九里 ${ }^{8)}$, 上田9) らが観測したものとま ったく同様のものでデンプン特有の典型的なスペクトルである。 また三品 ${ }^{10)}$, Adamic $^{11)}$ らが室温において観測したアミロースの それともよく類似している。この二重線スペクトルはラジカルと 1 個の水素原子核との相互作用によると解釈され，水素結合によ

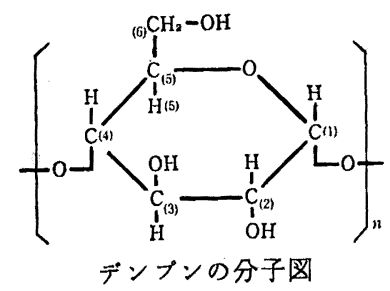




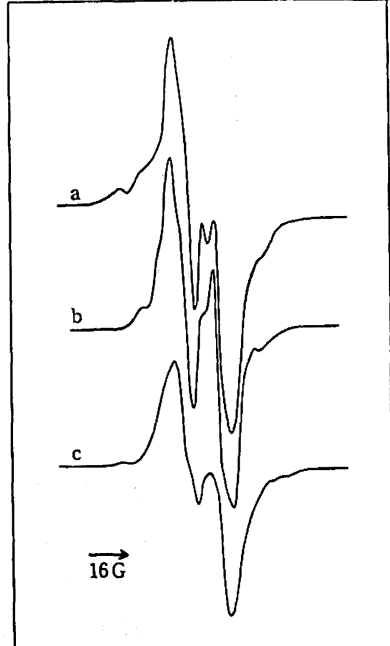

Fig. 3 ESR spectra of irradiated starch (a), formate starch (b) and glucose (c)

る水素か, ピラノース環に結合しているヒドロキシメチル基が切 断して $C_{(\varpi)}$ 炭素上のラジカルが生じ, このラジカルが $\mathrm{H}_{(6)}$ と相 互作用したものと提案されている。

ギ酸デンプンの ESR スペクトルはデンプンのそれとまったく 一致した。ギ酸エステルに関するシグナルが得られないのが特徵 的である。

一方, グルコースについてはデンプンと同様二重線である。こ のスペクトルは Williams ら) が観測したものと類似し, Baily ら9) Kよりラジカル種は - - $_{(6)}^{\mathrm{H}}$-OH であると提案された。 $r$ 線に より生成するラジカルは主として炭素と炭素执よび水素間の結果 の切断と考えられるが，もっとも可能性が高いのは C-H 結合の 切断である。これからデンプンの二重線シグナルは水素原子との 相互作用によると考光られるから, 得られた二重線は $\mathrm{C}_{(6)}-\mathrm{H}$ 結 合の切断により生ずる - C $_{(5)}$-O- とするのが妥当と考えられる。

図4にアルギン酸ナトリウム拈よびD-グルクロン酸の ESR ス ペクトルを示す。これらのスペクトルはそれぞれ $19 \mathrm{G}, 8 \mathrm{G}$ の線 幅を有する一重線でまったく hf が観測されない。このスペクトル は Williams ${ }^{2)}$, 九里 ${ }^{8)}$, 上田 ${ }^{9)} ら か ゙$ 観測したものとよく一致する。 彼らは $\mathrm{C}_{(5)}$-H 結合の切断により $-\mathrm{C}_{(5)}$-O- が生成したと提案し ている。このラジカルは $C_{(4)}$ ( $\beta$-炭素) に結合している水素によ る hf が観湘されない点が注目される。 $\mathrm{C}_{(4)}$ 上の $\beta$-水素と $\mathrm{C}_{(5)}$ ラジカルの方向が，炭素結合が平面ジグザグの場合よりもたがい に離れるためと解釈されるが，かりに $\beta-\mathrm{H}$ との相互作用が存在 するとしてもその影響が弱いため，シグナルの幅に隐されてしま らすのと判断される。

ポリエステルのカルボキシル基が 結合している $\alpha$-炭素上のラ ジカルはケトンと共鳴安定化することが知られている(16)17)。これ から得られた一重線シグナルはカルボキシル基により安定化され た $\mathrm{C}_{(6)}$ 上のラジカルであるとするのが妥当と考えられる。

以上の結果をもとに, 得られた酸化デンプンのスペクトルの解

16) S. Ohnishi, S. Sugimoto, I. Nitta, Bull. Chem. Soc. Jap., 37, 524(1964).

17) Y. Nozawa, ibid., 43, 657(1970).

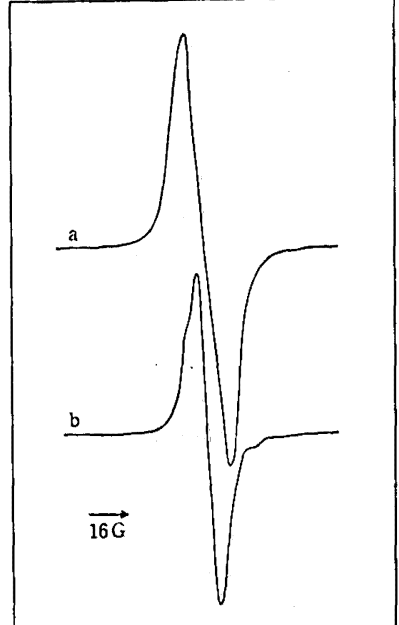

Fig. 4 ESR spectra of irradiated sodium alginate (a) and D-glucuronic acid (b)

釈を行なら。

因 5 に照射直後と $100^{\circ} \mathrm{C}, 60$ 分間熱処理した場合の差分スペ クトルを示す。このスペクトルは二重線シグナルで図 3 でのデン プンのそれによく一致した。これから罒 5-(a) 実線のスペクト ルは酸化デンプン固有のスペクトルにデンプンに拈けるシグナル が重なって観測されたるのと解釈される。

酸化デンプンは $\mathrm{C}_{(4)}-\mathrm{C}_{(3)}$ 結合が過ヨウ素酸で酸化切断され， アルデヒド基，さらにはカルボキシル基にまで変化すると考えら れる。用いた試料は少なくとも $75 \%$ のピラノース環が開裂して ジアルデヒドに酸化されている。このことは $25 \%$ 以下の酸化さ れないピラノース環が残存していることを示している。したがっ てこの二重線は過ヨウ素酸により酸化されないグルコース単位の $\mathrm{C}_{(6)}$ ラジカルによるスペクトルに帰属される。

照射した酸化デンプンを $100^{\circ} \mathrm{C} ， 60$ 分間熱処理したもののス ペクトルは非対称シグナルであるが，これは $g$ 值がわずかに異な る一重線が 2 種類重なったものと判断される。

本来, デンプンの二重線シグナルは安定で $150^{\circ} \mathrm{C}$ ぐらいまで 観測される。しかしながら，酸化デンプンの二重線シグナルは $100^{\circ} \mathrm{C}, 60$ 分間の熱処理で完全に減衰している。このことはデン

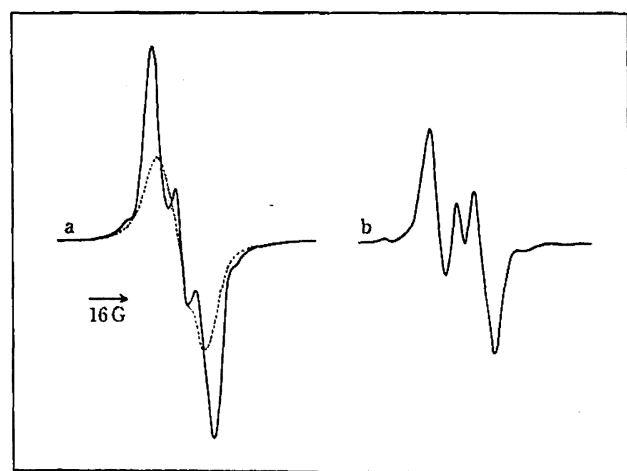

Fig. 5 ESR spectra of irradiated oxystarch

a : Immediately after irradiation (solid line), after the heat treatment at $100^{\circ} \mathrm{C}$ for $60 \mathrm{~min}$ (dotted line). $b$ : Difference between the two curves in a. 
プソの場合ラジカルがデンプンの粒状ミセル構造内に捕捉されて 安定化しているためと解釈されるが, 酸化デンプンの場合, 過 ウ素酸によりミセルが破壊されたために減衰がはやめられたと解 釈される。最終的に酸化デンプンの一重線が安定に残存するのは 酸化デンプンの化学的構造によるラジカルの安定化と考えること ができる。

以上の考察から, 酸化デンプンの一重線シグナルは $\mathrm{C}_{(1)}, \mathrm{C}_{(4)}$, $\mathrm{C}_{(2)}$ と $\mathrm{C}_{(\mathrm{s})}$ 炭素上のいずれかのラジカルに㷌属される。しかし ながら、アルデヒド基は分子運動性があり，ラジカルの減衰がは やいこと、およびギ酸デンプンに批いて環の水酸基にエステル化 したギ酸のラジカル -O-C、。牳成しないこと,などから判断 して, $\mathrm{C}_{(2)}, \mathrm{C}_{(\mathrm{s})}$ ラジカルは筧測されないと予想される。一方, $\mathrm{C}_{(1)}, \mathrm{C}_{(4)}$ ラジカルについては, $\mathrm{C}_{(2)}, \mathrm{C}_{(8)}$ 炭素がアルデヒド基で あるためケトンにより共鳴安定化されると予想される。しかも酸 化デンブンの実測スペクトルがより安定である事実を考立あわせ ると，実測シグナルは $C_{(4)}, C_{(1)}$ いずれかのラジカルに㷌属する ことが推察される。

つぎに酸化デンプンと尿素括よび PVA との反応生成物を照射 したときの ESR スペクトルを図6に示す。酸化デンプンを 100 ${ }^{\circ} \mathrm{C}, 60$ 分間熱処理した場合の図 2 におけるスペクトルを点線で 示した。尿素との反応生成物の場合，四から明らかなよらにわ ずかに幅広いシグナルが酸化デンプンの一重線に重なっているの がわかる。

箕浦の総説 ${ }^{18)}$ により尿素は $\mathrm{C}_{(8)}, \mathrm{C}_{(4)}$ の炭素に $-\mathrm{NHCONH}_{2}$ と

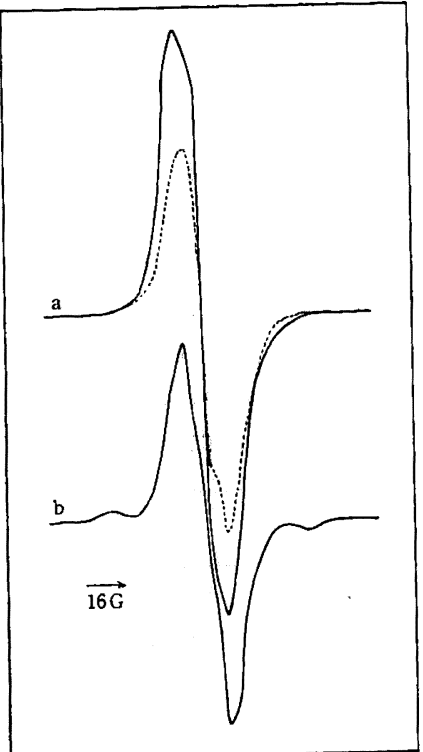

Fig. 6 ESR spectra of irradiated oxystarch-urea (a) and oxystarch-PVA (b)

Dotted line is the spectrum for the oxystarch system treated at $100^{\circ} \mathrm{C}$ for $60 \mathrm{~min}$.

18）箕浦有二，樹脂加工， 10，45(1961).
して結合することが知られている。一方，柏木 ${ }^{19}$ により照射され

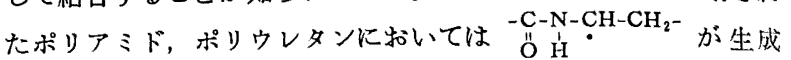
すると提案された。これから尿素との反応生成物の場合， $\mathrm{C}_{(3)}$ 找 よび $C_{(4)}$ 炭素上のラジカルの生成が予想される。そしてこのラ ジカルはまわりの $\mathrm{H}$ なは $\mathrm{N}^{14}$ の影響を受ける結果幅広いシグナ ルとして観測されたすのと推察される。

一方, 酸化デンプンと PVA との反応生成物の場合, ESR ス ペクトルはシグナルの両側に PVA に起因する三重線シグナル20) の一部が観測されるが, 全体としては一重線シグナルであり、こ のシグナルは酸化デンプンのそれによく類似している。

酸化デンプンのアルデヒド基は PVA の水酸基と反応して一部 ホルマール化すると推察される。かりに $C_{(2)}$ 炭素上にラジカル が生成するならば一重線になると予想されるが，ラジカルのまわ りの化学的構造を考兵ると, 酸化デンプンの $\mathrm{C}_{(1)}$ ラジカルのそ れによく類似することがわかる。以上の事実は，酸化デンプンに おけるラジカルは $\mathrm{C}_{(1)}$ 执よび $\mathrm{C}_{(4)}$ 炭素上のラジカルであるとす ることと矛盾しない。

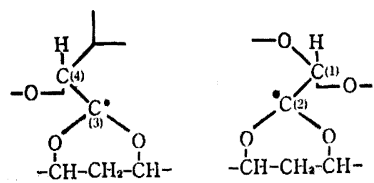
ホルマール化した $\mathrm{C}_{(2)}, \mathrm{C}_{(8)}$ ラシシカル<smiles>CO[C@H](C=O)C(C)C</smiles><smiles>CO[C](C)C(OC)OC</smiles>

酸化デンブンの $\mathrm{C}_{(1)}, \mathrm{C}_{(4)}$ ラシシカル

以上をまとめるとつぎのように結論される。室温において照射 された酸化デンプンの ESR スペクトルは試料を熱処理すること により，二重線スペクトルと， $g$ 值がわずかに異なる 2 種類の一 重線スペクトルの重なりであると判断される。前者はデンプンの シグナルに一致し, 酸化されないグルコース単位を含む酸化デン プンのヒドロキシメチル基の - $\mathrm{CHOH}$ と推察される。一方, 後者 は $100^{\circ} \mathrm{C}, 60$ 分間熱処理を行なっても安定であることから, 化 学構造的に安定化されていると判断される。一重線シグナルとし ては $\mathrm{C}_{(1)}, \mathrm{C}_{(4)}, \mathrm{C}_{(2)}, \mathrm{C}_{(3)}$ 炭素上のラジカルが考えられるが, 酸 化デンプンの尿素および PVA との反応生成物による結果からる 考虑して， $\mathrm{C}_{(1)}, \mathrm{C}_{(4)}$ いずれかのラジカルに㷌属される。しかし ながら、これら 2 種類の一重線シグナルが $\mathrm{C}_{(1)}, \mathrm{C}_{(4)}$ のいずれで あるかは現在のところ明確でない。

従来, 多糖類の照射ラジカルは分子構造の複雑さのためにその 䚻属が不明瞭であったが, 酸化デンプンの結果をあわせて考察す ると，定性的にその帰属が可能になるものと考えられる。

19) M. Kashiwagi, J. Polym. Sci., A 1, 189(1963)

20) S. Ogawa, J. Phys. Soc. Jap., 16, 1488(1960). 


\title{
ESR Spectra of $\gamma$-Irradiated Oxystarch
}

Yasuo Nozawa, Masami Suzuki and Fukuji Hrgashide

Shizuoka College of Pharmacy; Oshika, Shizuoka-shi 420 Japan

ESR spectra of $\gamma$-irradiated starch, starch formate, glucose, sodium alginate, D-glucuronic acid, oxystarch and oxycellulose have been determined at room temperature. Characteristic spectrum of a doublet was obtained in case of starch, and of a singlet in sodium alginate. The spectra of oxystarch and oxycellulose were similar to each other and complicated. Upon heating the irradiated oxycarbohydrates at $100^{\circ} \mathrm{C}$ for $60 \mathrm{~min}$ the spectrum changed to a broad singlet which may be considered to consist of two singlets having slightly different $g$-factors. The component of the esr signal that had disappeared on heating was similar to the doublet spectrum observed for the irradiated starch. The chemical structure of the radicals produced in the irradiated systems was discussed referring also to the result of irradiated compounds of oxystarch-urea and of oxystarch-polyvinylalcohol.

\section{各種同族列有機液体の表面張力の温度係数}

(1973 年 6 月 22 日受理)

\author{
渡辺昭* . 杉山幸男**
}

数種類の有機液体のノルマル化合物同族列の表面張力を $0^{\circ} \mathrm{C}$ と $60^{\circ} \mathrm{C}$ の間で測定し, つぎの実験式を 得た。 $\sigma=a-b t, a=c / T_{\mathrm{b}}+d$, そして $b=e / T_{\mathrm{b}}+f$, ここに $\sigma(\mathrm{dyn} / \mathrm{cm})$ は表面張力, $t\left({ }^{\circ} \mathrm{C}\right)$ は温度,

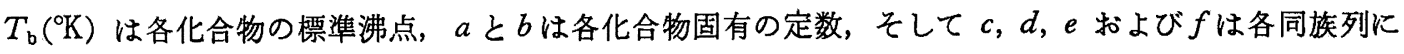
よって決まる定数である。これらの式で計算したのの值は実測值とよく一致した。

\section{1 緒言}

純有機液体の表面張力 $\sigma(\mathrm{dyn} / \mathrm{cm})$ の温度 $T(\mathrm{o} \mathrm{K})$ に上る変化 に関し，Mitra らによって次式が導かれている1”。

$$
\sigma^{5 / 6}=A-B T
$$

ここに $A$ および $B$ 法各化合物によって決まる定数である。この 式は非会合性液体炕は上く適合するが，会合性液体についてはあ まり広い範囲では成立しないとされている1。しかしのの温度変 化はきわめて直線に近いので, Jasper ら²) $n$-アルカン類と 1アルケン類について，また Katti らªアアルコール類について。 を測定し，次式を適用して $a$ 拈よび $b$ を求めている。

$$
\sigma=a-b t
$$

ここに $t\left({ }^{\circ} \mathrm{C}\right)$ は温度, $a$ 扰よび $b$ は各化合物により定まる定数

* 工業技術院 名古屋工業技術試験所, 462 名古屋市北区平 手町

** 名占屋大学工学部化学工学教室, 464 名古屋市 千種区不 老町

1) S. S. Mitra, N. K. Sanyal, J. Chem. Phys., 23, 1737 (1955).

2) J. J. Jasper, E. V. Kring, J. Phys. Chem., 59, 1019(1955).

3) S. S. Katti, S. Pathak, J. Chem. Eng. Data, 14, 73(1969).
である。その他，いくつかの化合物につき $a$ と $b$ 值が求められ ている゙〉。（1）扣よび（2）式中の定数の決定には各化合物につ き最低 2 点の測定値が必要である。なお，のと他の諸物性との関 係式がいろいろ提出されているが(5)日，のの推算に応用可能である のは式中の各定数值あるいは所要の温度における各物性值が得ら れる場合にかぎられる。

著者らはさきに常温で夜体である多くの直鎖状ノルマル化合物 の屈折率と $t$ との間に $(2)$ 式と同じ形の関係が成立し，また屈 折率の温度係数が各同族列に拈いて各化合物の標準沸点 $T_{\mathrm{b}}\left({ }^{\circ} \mathrm{K}\right)$ の逆数と直線関係になることを見いたしたがフ，のの温度係数に おいても同じ形の次式の関係の有無を検討したところ，いくつか の同族列に括いて成立することがわかった。

$$
\begin{aligned}
& a=\frac{c}{T_{\mathrm{b}}}+d \\
& b=\frac{e}{T_{\mathrm{b}}}+f
\end{aligned}
$$

4）有機合成化学協会, “溶剈ポケットブック”, オーム社 (1967) p. 87.

5) R. C. Reid, T. K. Sherwood, "The Properties of Gases and Liquids", McGraw-Hill Book Co., New York (1966) p. 371.

6) P. I. Gold, G. J. Ogle, Chem. Eng., May 19, 192(1969).

7）渡辺 昭，諸戸定正，杉山幸男，工化，74，2234(1971). 